\title{
AKTIVITAS ANTIOKSIDAN EKSTRAK METANOL \\ KULIT JENGKOL (Pithecellobium jiringa) \\ DENGAN TIGA WAKTU MASERASI
}

\author{
Alfin Surya ${ }^{1}$, Yulia Yesti ${ }^{2}$ \\ ${ }^{1}$ Akademi Analis Kesehatan Pekanbaru J1. Riau Ujung No. 73 Pekanbaru \\ ${ }^{2}$ STIKes Fort De Kock Bukittinggi, Jl. Soekarno Hatta No.11 Bukittinggi
}

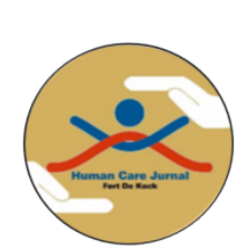

Human Care

INFO ARTIKEL:

Sejarah Artikel:

Diterima: 20-11-

2017

Disetujui: 21-112017

Corresponding

Author:

alfin.surya@ya

hoo.co.id

Keyword:

Antioxsidant,

Method DPPH

Tersedia online

di:

https://ojs.fdk.ac .id/index.php/h umancare
ABSTRAK. Kulit jengkol (Pithecellobium jiringa) sering ditemui di lingkungan sebagai limbah organik terutama di pasar-pasar tradisional. Selain merusak estetik lingkungan juga tidak memberikan nilai ekonomis. Untuk itu perlu dilakukan pemanfaatan kulit jengkol salah satunya sebagai antioksidan. Penelitian ini bertujuan untuk menentukan aktivitas antioksidan berdasarkan perbedaan waktu maserasi pada ekstrak metanol dari tanaman Pithecellobium jiringa (kulit jengkol). Penelitian ini mengunakan metode DPPH (2,2 diphenyl-1-picrylhydrazyl) sehingga menghasilkan $\mathrm{IC}_{50}$ : pada 24 jam sebesar $51,1387 \mu \mathrm{g} / \mathrm{mL}$, pada 48 jam sebesar $40,2855 \mu \mathrm{g} / \mathrm{mL}$ sedangkan pada 72 jam sebesar $22,5788 \mu \mathrm{g} / \mathrm{mL}$. Hasil $\mathrm{IC}_{50}$ terbaik dari penelitian ini diperoleh pada waktu maserasi 72 Jam yaitu dengan $22,5788 \mu \mathrm{g} / \mathrm{mL}$ sudah dapat menghambat 50\% DPPH sebagai sumber radikal.

ABSTRACT. Jengkol Skin (Pithecellobium jiringa) is often found in the environment as organic waste, especially in traditional markets. Besides damaging environmental aesthetics, it does not provide economic value. For this reason, it is necessary to use jengkol skin as an antioxidant. This study aims to determine the antioxidant activity based on the difference of maceration time on methanol extract from Pithecellobium jiringa plant (jengkol skin). This study used the DPPH method (2,2 diphenyl-1picrylhydrazyl) to produce $I C_{50}$ : at 24 hours at $51.1387 \mu \mathrm{g} / \mathrm{mL}$ at 48 hours at $40.2855 \mu \mathrm{g} / \mathrm{mL}$ while at 72 hours at $22.5788 \mu \mathrm{g} / \mathrm{mL}$. The best $I_{50}$ results from this study were obtained at 72 hours of maseration time with $22,5788 \mu \mathrm{g} / \mathrm{mL}$ have been able to inhibit $50 \%$ DPPH as radical source.

\section{PENDAHULUAN}

Kulit Jengkol (Pithecellobium jiringa) selama ini tergolong limbah organik yang berserakan di pasar tradisional dan tidak memberikan nilai ekonomis. (Hutasuhut, 13 Maret 2012)..Namun, sebenarnya sudah ada penelitian yang dilakukan terhadap jengkol maupun kulitnya. Para peneliti mencoba memanfaatkan kandungan dalam jengkol maupun kulitnya untuk digunakan dalam kehidupan. Ekstrak etanol kulit jengkol dapat dimanfaatkan sebagai antibakteri terhadap Streptococcus mutans, Staphylococcusaureus, dan Escherichia coli (Nurussakinah, 2010). Senyawa-senyawa yang mempunyai potensi sebagai antioksidan umumnya merupakan senyawa flavonoid, fenolik dan alkaloid. Senyawa flavonoid dan polifenol bersifat antioksidan, antikanker, antiseptik, dan antiinflamasi. 
Berdasarkan uraian tersebut, maka peneliti tertarik untuk melakukan studi tentang kandungan flavonoid dari ekstrak metanol kulit jengkol (Pithecellobium jiringa) sebagai antioksidan. Dalam menghambat DPPH sebagai sumber radikal.

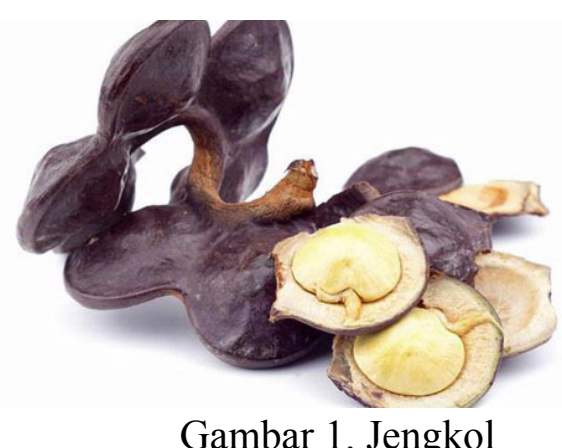

\section{BAHAN DAN METODE}

Sampel yang digunakan dalam penelitian ini adalah kulit jengkol Pithecellobium jiringa yang diperoleh dari pasar Panam Pekanbaru. Bahan yang digunakan adalah, metanol, $\mathrm{HCl}$ pekat logam Mg, metanol grade HPLC, 2,2 diphenyl-1-picrylhydrazyl (DPPH), vitamin $\mathrm{C}$, kapas, aluminium foil dan aquades.

\section{Uji fitokimia :}

- Uji Fenolik

Sebanyak tiga tetes larutan ekstrak methanol diteteskan pada plat tetes dan ditambahkan 1-2 tetes larutan besi (III) klorida 1\%. Bila terbentuk warna biru/ungu,berarti terdapat senyawa fenolik. (Khomsan,2005).

- Uji Flavonoid

Lapisan air sebanyak lima tetes dimasukkan ke tabung reaksi kemudian ditambah 1-2 potongan kecil logam magnesium dan beberapa tetes asam klorida pekat. Terjadinya warna jingga, merah muda sampai merah menandakan adanya senyawa flavonoid. (Suarez, dkk 2010)
2. Uji aktivitas antioksidan dengan metode $\operatorname{DPPH}(1,1$ - diphenyl-2-picrylhydrazyl)

Uji aktivitas antioksidan dilakukan menggunakan mikroplate readertwo fold delution dengan metode DPPH (Taie et al., 2008).Sampel sebanyak $2 \mathrm{mg}$ dilarutkan dalam $2 \mathrm{~mL} \mathrm{MeOH}$ sehingga konsentrasi sampel menjadi $1000 \mu \mathrm{g} / \mathrm{mL}$. Baris A dimasukkan sampel sebanyak $100 \mu \mathrm{L}$ (plate terdiri dari baris A-H masing-masing berjumlah 12 sumur).

Sebanyak $50 \mu \mathrm{L} \mathrm{MeOH}$ dimasukkan pada masing-masing sumur pada baris B-F. Baris A dipipet sebanyak $50 \mu \mathrm{L}$ dan dimasukkan ke baris $\mathrm{B}$, baris $\mathrm{B}$ dipipet 50 $\mu \mathrm{L}$ dimasukkan ke baris $\mathrm{C}$ dan dilakukan sampai baris $\mathrm{F}$, baris $\mathrm{F}$ dipipet $50 \mu \mathrm{L}$ lalu dibuang, sehingga didapatkan konsentrasi $1000 \mu \mathrm{g} / \mathrm{mL}, 500 \mu \mathrm{g} / \mathrm{mL}, 250 \mu \mathrm{g} / \mathrm{mL}, 125$ $\mu \mathrm{g} / \mathrm{mL}, \quad 62,5 \mu \mathrm{g} / \mathrm{mL}$ dan $31,25 \mu \mathrm{g} / \mathrm{mL}$. Sedangkan pada baris G-H diisi dengan MeOH50 $\mu \mathrm{L}$, khusus pada baris $\mathrm{H}$ diisi hanya sumur 1-6. Baris A-G ditambahkan DPPH sebanyak $80 \mu \mathrm{L}$ dengan konsentrasi $80 \mu \mathrm{g} / \mathrm{mL}$, kemudian diinkubasi selama 30 menit. Aktivitas ekstrak metanol dalam menghambat radikal DPPH diukur sebagai penurunan absorbansi DPPH dengan microplate reader dan olah data. Larutan asam askorbat digunakan sebagai kontrol $(+)$. Nilai \% inhibisi dihitung dengan rumus sebagai berikut:

$\%$ Hambatan $=\frac{\left(A_{\text {kontrol }}-A_{\text {sampel }}\right)}{A_{\text {kontrol }}} \times 100 \%$

Ket :

$\mathrm{A}_{\text {kontrol }}=$ Absorbansi tidak mengandung sampel

$\mathrm{A}_{\text {sampel }}=$ Absorbansi sampel 


\section{HASIL DAN PEMBAHASAN}

\section{Hasil Uji Fitokimia}

Hasil uji fitokimia menunjukkan adanya senyawa flavonoid dan fenolik. Hasil uji fitokimia sebagai berikut :

Tabel. 1 Uji fitokimia

\begin{tabular}{lccc}
\hline No & Senyawa & Reagen & Keterangan \\
\hline 1. & Flavonoid & $\mathrm{HClp}$ & + \\
2. & Fenolik & $\mathrm{FeCl}_{3}$ & + \\
& \multicolumn{3}{c}{$1 \%$} \\
\hline \multicolumn{4}{l}{ Keterangan: $(-)=$ tidak ada, $(+)=$ ada }
\end{tabular}

Hasil $\mathrm{IC}_{50}$ dari Tabel 1 memperlihatkan bahwa ekstrak metanol secara keseluruhan memiliki aktivitas antioksidan yang sangat kuat terutama pada waktu maserasi 72 jam hal ini disebabkan semakin banyak senyawa antioksidan yang terekstrak dibandingkan pada 24 jam maupun 48 jam dengan demikian semakin kecil nilai IC $_{50}$ maka akan semakin kuat aktivitas antioksidan suatu sampel.

\section{Uji Aktivitas Antioksidan}

Analisis aktivitas antioksidan menggunakan metode DPPH dengan microplate reader 96 well (Berthold technologies) pada panjang gelombang 520 $\mathrm{nm}$ menghasilkan nilai $\mathrm{IC}_{50}$ untuk sampel ekstrak methanol kulit jengkol seperti terlihat pada tabel berikut :
Tabel 2. Pengukuran antioksidan dengan DPPH

\begin{tabular}{|c|c|c|c|c|}
\hline Ekstrak & $\begin{array}{l}\text { Maserasi } \\
\text { (metanol) }\end{array}$ & $\begin{array}{c}\text { Konsentr } \\
\text { asi } \\
(\mu \mathrm{g} / \mathrm{mL})\end{array}$ & $\begin{array}{c}\% \\
\text { Inhibisi }\end{array}$ & $\begin{array}{c}\mathrm{IC}_{50} \\
(\mu \mathrm{g} / \mathrm{mL})\end{array}$ \\
\hline & $24 \mathrm{Jam}$ & $\begin{array}{c}1000 \\
500 \\
250 \\
125 \\
62,5 \\
31,25 \\
\end{array}$ & $\begin{array}{l}98,494 \\
88,377 \\
76,814 \\
66,697 \\
52,424 \\
41,23\end{array}$ & 51,1387 \\
\hline Metanol & $48 \mathrm{Jam}$ & $\begin{array}{c}1000 \\
500 \\
250 \\
125 \\
62,5 \\
31,25\end{array}$ & $\begin{array}{l}99,73 \\
88,82 \\
76,38 \\
65,48 \\
58,27 \\
46,38\end{array}$ & 40,2855 \\
\hline . & $72 \mathrm{Jam}$ & $\begin{array}{c}1000 \\
500 \\
250 \\
125 \\
62,5 \\
31,25\end{array}$ & $\begin{array}{l}95,128 \\
86,556 \\
80,692 \\
70,496 \\
63,188 \\
52,722\end{array}$ & 22,5788 \\
\hline $\begin{array}{c}\text { Asam } \\
\text { Askorbat }\end{array}$ & $1 \mathrm{Jam}$ & $\begin{array}{c}100 \\
50 \\
25 \\
\\
12,5 \\
6,25 \\
3,125\end{array}$ & $\begin{array}{c}98,8111 \\
84,0159 \\
72,2589 \\
60,502 \\
48,4808 \\
33,5535\end{array}$ & 7,2849 \\
\hline
\end{tabular}

\section{PEMBAHASAN}

Analisis fitokimia dilakukan untuk menentukan golongan utama dari senyawasenyawa aktif dari ekstrak metanol dari kulit jengkol yang memiliki aktivitas antioksidan. Analisis ini meliputi uji flavonoid dan fenolik. Senyawa metabolit sekunder dihasilkan oleh tumbuhan untuk mempertahankan diri dari serangan serangga dan hama. Hasil analisis yang diperoleh menunjukkan bahwa kulit jengkol mengandung senyawa flavonoid, fenolik (Tabel 1) dan terlihat pada gambar (gambar 2) Senyawa flavonoid mempunyai khasiat sebagai antioksidan dengan menghambat berbagai reaksi oksidasi. 


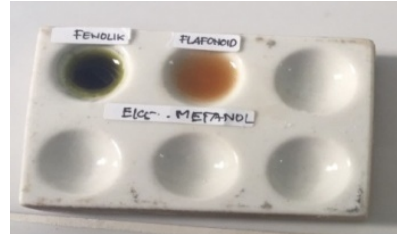

Gambar 2. Uji Fitokimia

Pelarut yang digunakan dalam penelitian ini adalah metanol yang mampu melarutkan dan menarik senyawa- senyawa yang bersifat polar.Metode yang digunakan dalam pengujian aktivitas antioksidan adalah DPPH.

Nilai $\mathrm{IC}_{50}$ merupakan konsentrasi senyawa antioksidan yang memberikan inhibisi sebesar 50\% yang artinya pada konsentrasi tersebut antioksidan dapat menghambat radikal bebas sebesar $50 \%$. Pada kontrol positif digunakan Asam Askorbat yang berfungsi sebagai antioksidan untuk menangkap radikal bebas dan mencegah terjadinya reaksi berantai (Pratiwi et al., 2006) didapatkan $\mathrm{IC}_{50}$ sebesar 7,2849 $\mu \mathrm{g} / \mathrm{mL}$, aktivitas antioksidannya yang sangat kuat karena, merupakan senyawa yang sudah murni. Pada kulit jengkol didapatkan nilai $\mathrm{IC}_{50}$ berdasarkan waktu maserasi yang berbeda, pada 24 jam sebesar 51,1387 $\mu \mathrm{g} / \mathrm{mL}$, pada 48 jam sebesar $22,578 \mu \mathrm{g} / \mathrm{mL}$ sedangkan pada 72 jam sebesar 22,5788 $\mu \mathrm{g} / \mathrm{mL}$ dari hasil $\mathrm{IC}_{50}$ yang diperoleh pada waktu maserasi 72 memberikan hasil terkuat. Hal ini menunjukkan semakin lama waktu maserasi akan semakin banyak senyawa yang bersifat antioksidan yang terekstraks, sehingga dapat menghambat radikal bebas dari DDPH menjadi lebih efektif dibandingkan dengan waktu maserasi 24 jam dan 48 jam.

\section{KESIMPULAN.}

Hasil analisis pengujian aktivitas antioksidan dengan mengunakan perbedaan waktu maserasi yang berbeda, secara keseluruhan diperoleh $\mathrm{IC}_{50}$ yang terkuat yaitu pada waktu maserasi selama 72 jam dengan nilai $\mathrm{IC}_{50} 22,5788 \mu \mathrm{g} / \mathrm{mL}$ sehingga diharapkan dapat menjadi sumber antioksidan alami

\section{DAFTAR PUSTAKA}

Agestiawaji, R., Sugrani, A., 2009. Flavonoid (Quercetin), Makalah Kimia Organik Bahan Alam Program S2 Kimia, Fakultas Matematika dan Ilmu Pengetahuan Alam, Universitas Hasanuddin.

Barus, P., Pemanfaatan Bahan Pengawet dan Antioksidan Alami pada Industri Bahan Makanan, Pidato Pengukuhan Jabatan Guru Besar Tetap dalam Bidang Ilmu Kimia Analitik pada Fakultas MIPA diucapkan di Hadapan Rapat Terbuka Universitas Sumatera Utara 3 Oktober 2009

Hutasuhut, A.B., 2012. Banjir, Jengkol, Rahudman, http://www.hariansumutpos. com/2012/01/23377/banjir-jengkolrahudman.html, 13 Oktober 2014

Hutauruk, J.E., 2010. Isolasi Senyawa Flavonoida Dari Kulit Buah Tanaman Jengkol (Pithecellobium lobatum Benth.), Skripsi, FMIPA, USU

Lay, A., 2009. Pembuang Kulit Jengkol sedang Diintai, http://www.borneotribune.com/ponti anak-kota/pembuang-kulit-jengkolsedang diintai.html.

Nurussakinah, 2010.Skrinning Fitokimia dan Uji Aktivitas Antibakteri Ekstrak Kulit Buah Tanaman Jengkol (Pithecellobium jiringa (Jack) Prain) Terhadap Bakteri Streptococcus mutans, Staphylococcus aureus, dan Eschericia coli, Skripsi,Fakultas Farmasi, USU, Medan 
Pratiwi, Dewi \& Harapini, M 2006. Nilai peroksida dan aktivitas antiradikal bebas diphenylpicril hydrazil hydrate (DPPH) ekstrak methanol knema laurina. Majalah Farmasi Indonesia, 17(1) : 32-36.

Rachmawati, H., 2010. Antioksidan, rarafarmasi.staff.umm.ac.id/files/201 0 /01/ANTIOKSIDAN.ppt, (diakses 20 Oktober 2014)

Rahmat, H., 2009. Identifikasi Senyawa Flavonoid Pada Sayuran Indigenous Jawa Barat, Skripsi, Fakultas Teknologi Pertanian, Institut Pertanian Bogor, Bogor

Rohman, A., Riyanto, S., 2005. Daya Antioksidan Ekstrak Etanol Daun Kemuning (Murraya paniculata (L) Jack) secara in vitro, Majalah Farmasi Indonesia, 16 (3), 2005

Utami, S., Kosela, S., dan Hanafi, M., 2006. Efek Peredaman Radikal Bebas 1,1Difenil-2-pikrilhidrazil (DPPH) dan Uji Toksisitas Pendahuluan Terhadap Larva Udang Artemia Salina Leach dari Ekstrak Aseton Daging Buah Sesoot (Garcinia picrorrhiza MIQ.), Jurnal Kedokteran Yarsi, 14 (3).

Suarez, B., Alvarez, A., Garcia, Y., Barrio, G. 2010. Phenolic Profiles, Antioxidant Activity and In Vitro Antiviral Properties of Apple Pomace. Journal Food Chemistry. $120: 339-342$
Taie,H.A.A, El-Mergawi, R. \& Radwan, S. 2008. Isoflavonoid, flavonoid, phenolic acid, and antioxidant activity of soybean seeds as affected by organic and bioorganic fertilization. Journal of Agicultural and Environmental Science 4 (2): 207-213. 